\title{
PENGARUH KEARIFAN LOKAL TERHADAP KELESTARIAN LINGKUNGAN ALAM DI KAMPUNG NAGA, TASIKMALAYA DAN DI SUNGAI JINGAH, BANJARMASIN : ARTIKEL KONSEPTUAL
}

\author{
Yogi Kuswara \\ Pendidikan Ilmu Pengetahuan Sosial, FKIP, Universitas Lambung Mangkurat \\ Jl. Brigjen H. Hasan Basri, Banjarmasin - Kalimantan Selatan, 70123 \\ e-mail : yogikuswara223@gmail.com
}

\begin{abstract}
Local wisdom is a collection of various local knowledge and experiences of people in an area. In a local wisdom that exists in an area there are useful values (positive in nature), this is because local wisdom is created from social values that are respected and upheld by the community and has a function as a guide in behaving with others. society/humans, nature, and with God. In this article, we will discuss the influence of local wisdom on environmental sustainability, especially in the Kampung Naga, Tasikmalaya and in the Sungai Jingah, Banjarmasin. The method used is this article is descriptive qualitative, with data sources form literature studies. The purpose of this conceptual article is to find out the influence of local wisdom in preserving the environmnet in an area, especially in Kampung Naga Tasikmalaya and in the Sungai Jingah, Banjarmasin.
\end{abstract}

Keywords : Local wisdom, natural environment, Kampung Naga, Sungai Jingah

\begin{abstract}
ABSTRAK
Kearifan lokal yaitu kumpulan dari berbagai pengetahuan lokal dan pengalaman masyarakat disuatu daerah. Pada suatu kearifan lokal yang ada disuatu daerah terdapat nilai - nilai yang bermanfaat (sifatnya postitif), hal tersebut karena kearifan lokal tercipta dari nilai - nilai sosial yang dihormati serta dijunjung tinggi oleh masyarakat dan memiliki fungsi sebagai suatu pedoman dalam bertingkah laku dengan sesama masyarakat / manusia, alam, maupun dengan Tuhan. Pada artikel ini akan dibahas mengenai pengaruh kearifan lokal pada kelestarian lingkungan terutama di daerah Kampung Naga di Tasikmalaya, dan di daerah Sungai Jingah, Banjarmasin. Metode yang digunakan pada artikel ini yaitu deskriptif kualitatif, dengan sumber data dari studi literatur. Tujuan dari artikel konseptual ini yaitu untuk mengetahui pengaruh kearifan lokal dalam menjaga kelestarian lingkungan yang ada disuatu daerah terutama yang ada di Kampung Naga Tasikmalaya dan yang di di daerah Sungai Jingah, Banjarmasin.
\end{abstract}

Kata Kunci : Kearifan lokal, lingkungan alam, Kampung Naga, Sungai Jingah 


\section{PENDAHULUAN}

Kearifan lokal berasal dari 2 kata, yakni kearifan (wisdom) dan lokal (local). Pada umumnya kearifan lokal dimaknai sebagai suatu gagasan disuatu tempat (lokal) yang sifatnya penuh akan nilai kebaikan yang terkandung didalamnya yang mana hal tersebut diikuti/dituruti oleh setiap anggota masyarakat (Nirman, 2019). Kearifan lokal yaitu sistem lingkungan yang ada ditengah masyarakat yang didalamnya terdapat kehidupan sosial, budaya, politik dan ekonomi. Kearifan lokal juga yakni suatu ciri khas dari suatu daerah. Kearifan lokal ini bentuk / wujudnya dapat berupa ide ataupun kegiatan yang kaitannya dengan interaksi manusia dengan manusia, manusia dengan lingkungannya serta manusia dengan Tuhan, sehingga kearifan lokal memiliki peranan dalam menjaga kestrabilan sosial dan menjaga atas semua kegiatan manusia antara pemilik kehidupan dengan kehidupan masyarakat (Jumriani, 2021). Kearifan lokal mempunyai ciri berupa sifatnya yang tidak statis (dinamis), berkelanjutan serta masih bisa diterima oleh masyarakatnya (Thamrin, 2013). Adanya kearifan lokal ini mempunyai banyak peranan / fungsi (Qodariah, 2013). Beberapa fungsi dari kearifan lokal itu yaitu : sebagai konservasi dan wujud pelestarian SDA (Sumber Daya Alam), sebagai bentuk pengembangan SDM (Sumber Daya Manusia), sebagai pengembangan dari suatu ilmu pengetahuan serta sebagai pengembangan dari suatu kebudayaan, sebagai suatu kepercayaan, petuah serta pantangan disuatu daerah, bermakna sosial contohnya seperti upacara integrasi suatu kerabat, bermakna sebagai moral \& etika, dan yang terakhir sebagai makna politik contohnya kekausaan patron client (Sartini, 2004).

Kearifan lokal merupakan pengetahuan lokal dari masyarakat suatu daerah yang mana hal tersebut menjadi ciri khas (budaya) dari daerah itu yang telah berkembang sangat lama yang berasal dari hubungan timbal - balik dari masyakat / manusia dengan lingkungan, yang kemudian di yakini, dilaksanakan dan dijadikan sebagai acuan dalam beraktivitas serta kemudian di wariskan kepada generasi selanjutnya. Kearifan lokal memiliki peranan dalam mengontrol perilaku / aktivitas masyarakat, hal tersebut memiliki fungsi penting dalam menjaga kelestraian lingkungan / SDA disuatu daerah. Kearifan lokal juga memiliki peranan dalam mengajarkan sikap berinteraksi anatar manusia dengan alam, melalui adanya suatu mitos, ritual adat dan tabu (Dewi, 2016).

Pada hakikatnya di alam tidak ada sesuatu yang hilang, yang ada adalah perubahan menjadi suatu bentuk yang baru, seperti cntohnya yang awalnya pohon / kayu yang ada di hutan diolah menjadi bnetuk baru, berupa alat / perabotan yang dapat kita temui di rumah / kantor. Tidak hanya pohon saja, tanah, batu dan pasir juga memiliki perubahan menjadi baja / bijih besi yang kemudian diubah lagi menjadi suatu gedung / bangunan. Banhyaknya perubahan yang dilakukan manusia tersebut, tidak diimbangi dengan upaya pelestarian lingkungannya, sehingga di masa sekarang ini kondisi alam sudah tidak sebaik dulu. Terjadinya emanasan global yang menyebabkan suhu bumi semakin panas, es kutub 
mencair, membludaknya sampah plastik yang menyebabkan banjir, limbah pabrik yang mencemari lingkungan (terutama lingkungan air dan udara).

Banyak nya bencana alam / kerusakan alam yang terjadi (seperti banjir, kebakaran hutan, pencemaran lingkungan (air, udara, tanah), dan kerusakan alam lainnya) menjadi masalah yang serius dan bahkan dapat menjadi ancaman yang serius untuk keberlangsungan kehidupan manusia dan makhluk hidup lainnya di masa mendatang. Penyebab utama dari munculnya kerusakan - kerusakan alam itu adalah dari manusia itu sendiri. Masih banyak manusia yang egois yang hanya mementingkan kepentingan individu / suatu kelompok saja, tidak adanya pemikiran bahwa hal tersebut memiliki hubungan timbal - balik antara tindakan manusia tersebut dengan alam dalam ekosistem yang ada. Maka dengan adanya permasalahan itu, maka munculah saran untuk kembali ke kehidupan yang sifatnya tradisional (adanya pembatasan dalam mengeksploitasi alam sekitar dan hidup dalam kesederhanaan). Kearifan lokal layak dijadikan sebagai suatu rujukan dalam menjamin kehidupan bumi untuk jangka waktu yang panjang kedepannya. Hal tersebut karena sebanyak $80 \%$ kearifan lokal yang ada di bumi mempunyai kearifan lokal yang memiliki fungsi / nilai - nilai positif yang dapat dijadikan sebagai rujukan dalam hidup, sehingga diharapkan di masa modern sekarang ini yang tidak dapat terlepas dari ekploitasi dan kerusakan alam masih memilki harapan untuk hidup yang lebih panjang lagi, dengan mengacu kepada kearifan lokal (Darusman, 2016).

Dengan banyak nya kerusakan alam yang terjadi, maka untuk selalu mengintakan semua orang akan pentingnya menjada lingkungan, maka ditentukanlah hari peringatan secara universal / global seperti misalnya hari hutan sedunia pad tanggal 21 maret, hal tersebut ditujukan untuk memperingati dan mengingatkan semua orang akan pentingnya peran hutan dalam kehidupan. Selain hari hutan sedunia, terdapat juga hari lingkungan hidup pada tanggal 5 juni sebagai peringatan untuk selalu memanfaatkan sumber daya alam secukupnya dan tidak merusaknya. Terdapat juga hari bumi pada tanggal 22 april yang tujuannya untuk meningkatkan kesadaran manusia terhadap kesehatan bumi. Dibuatnya peringatan hari mengenai kelestarian lingkungan, hal tersebut menjadi bentuk kepedulian dalam mengingatkan semua orang terhadap penting nya menjaga lingkungan, sehingga permasalahan kerusakan lingkungan / alam tidak hanya sekedar perhatian dari beberapa kelompok saja, tetapi perhatian kita semua (seluruh lapisan masyarakat). Meskipun sekarang ini sudah banyak sekali masyarakat yang peduli lingkungan, tetapi hal itu masih belum cukup, karena mayoritas masyakarat masih acuh tak acuh terhadap permasalahan lingkungan yang ada. Bertambahnya masyakarat yang peduli terhadap kerusakan lingkungan, hal tersebut terjadi karena pengetahuan masyakarakat mengenai lingkungan semakin banyak dan memiliki pengalaman nyata dalam melihat dan merasakan kondisi kerusakan alam yang ada disekitar mereka.

Dengan adanya permasalahan lingkungan tersebut, serta adanya fungsi / nilai - nilai positif dari kearifan lokal di suatu daerah, yang mana salah satu fungsi dari kearifan lokal 
yaitu sebagai konservasi dan wujud pelestarian SDA (Sumber Daya Alam), maka kearifan lokal dapat menjadi salah satu upaya dalam menjaga kelestarian lignkungan. Pada pembahasan artikel ini, bahasan kearifan lokal yang dibahas yaitu kearifan lokal daerah Kampung Naga, Tasimalaya dan daerah Sungai Jingah, Banjarmasin.

Kampung Naga berlokasi di desa Negalsari, Kec. Salawu, Tasikmalaya, Jawa Barat. Di Kampung Naga kearifan lokal masih dinjunjung sangat tinggi sampai sekarang ini. Masyarakat di Kampung Naga masih memiliki hubungan yang sangat erat dengan lingkungan alam disekitarnya, masyakaratnya telah hidup berdampingan dan selaras dengan alam sejak dari dahulu sampai sekarang. Pada sumber ajarannya masyarakat Kampung Naga masih memakai ajararan dari nenek moyang. Di daerah Kampung Naga terdapat wilayah hutan yang dikeramatkan dan juga terdapat hutan larangan yang tidak boleh dimasuki oleh manusia.

Selain kearifan lokal di Kampung Naga, bahasan kearifan lokal lainnya yaitu kearifan lokal yang ada di Sungai Jingah. Sungai Jingah sering juga disebut dengan sebutan kampung tua yang ada di salah satu kelurahan di Banjarmasin. Letak mayoritas perkampungan masyarakat Sungai Jingah terletak/bermukim di daerah bantaran sungai. Di Sungai Jingah, seiring berkembangnya teknologi, infrastuktur dan jaman, kehidupan masyarakat Sungai Jingah mengalami perubahan, baik masyarakat yang di bantaran sungai maupun bukan. Adanya kemajuan fasilitas seperti adanya jalan darat dan disediakannya air bersih, berpengaruh dalam aktivitas masyarakat dalam memanfaatkan sungai. Yang pada awalnya masyarakat menggunakan transportasi sungai, sekarang sudah banyak yang beralih ke trasnportasi darat, kemudian dengan adanya kesediaan air bersih, masyarakat menjadi tahu bahwa tidak baik jika mandi / mencuci di sungai, karena bagaimanapun juga air sungai itu kotor dan tidak baik untuk kesehatan. Sehingga lambat laun masyakarat Sungai Jingah tidak lagi mandi dan mencuci di sungai (Putro, 2020). Dengan adanya hal tersebut maka kualitas air sungai akan tetap terjaga dan tidak tercemar oleh zat kimia detergen dan zat kimia lain yang dapat mencemari sungai secara langsung. Tetapi meskipun demikian, di Sungai Jingah juga terdapat kaerifan lokal berupa kain Sasirangan, yang mana masyakarat nya masih membuang limbah sisa produksi kain ke sungai tanpa diolah terlebih dahulu. Sehingga dari 2 hal itu aktivitas masyakarat masih kontras, ada yang berperan dalam mengurangi pencemaran air, dan ada yang masih mencemari sungai.

Dengan pengambilan dua kearifan lokal di dua lokasi yang berbeda, tetapi kearifan lokal menunjukan bahwa adanya hubungan manusia dengan lingkungan sangat erat kaitannya. Dengan membangkitkan dan menjunjung tinggi kearifan lokal yang memilki peran / nilai - nilai positif adalah salah satu cara untuk menjaga kelestarian lingkungan dan dapat meredam sikap eksploitatif manusia atas alam (Nurkamilah, 2018). 


\section{PEMBAHASAN}

\section{A. Kearifan Lokal Dalam Pelestarian Lingkungan Alam Di Kampung Naga, Tasikmalaya}

Seiring majunya teknologi dan ilmu pengetahuan, maka seiring pula kerusakan lingkungan yang ada. Dengan kemajuan IPTEK tersebut mendorong manusia untuk merusak ligkungan dengan melakukan eksploitasi, seperti misalnya membuang limbah pabrik ke sungai, dan bahkan menenbang pohon secara liar. Hal tersebutdapat terjadi karena adanya kemajuan IPTEK yang diiringi dengn sifat egois manusia dalam mementingkan diri sendiri, sehingga tidak ada upaya untuk memelihara lingkungan hidup, yang ada hanya untuk mengambil sumber daya alamnya saja.

Di masa modern ini harusya semua orang dapat berfikir secara global dan dapat bertindak secara lokal, dalam menghadapi permasalahan kerusakan lingkungan secara global. Sudah dapat terlihat dengan jelas, bahwa bumi sudah mengalami kerusakan dan akan susah untuk diperbaiki. Maka saat ini tidak ada pilihan lain selain untuk memperlambat kerusakan alam dengan berpikir dan bertindak dengan mengacu pada budaya lokal daerah / kearifan lokal. Pada kepercayaan masyarakat lokal, keperyaan itu terbentuk oleh sejarah, dan sudah diyakini secara turun temurun, dari generasi ke generasi. Dengan demikian maka akan munculah kearifan lokal berupa larangan, pantangan, serta anjuran yang menjadi pedoman hidup masyarakat lokal, seperti pada masyarakat Kampung Naga. Pada masyarakat lokal terutama di daerah Kampung Naga, masih banyak ditemukan larangan atau pantangan yang masih diyakini dan dijunjung tinggi oleh masyarakat Kampung Naga.

Berikut ini beberapa kearifan lokal berupa larangan / pantangan / anjuran yang ada di Kampung Naga dan pengaruhnya terhadap kelestarian lingkungan :

\begin{tabular}{|c|c|c|}
\hline No. & $\begin{array}{c}\text { Pantangan / Larangan / } \\
\text { Anjuran }\end{array}$ & Pengaruh terhadap Lingkungan \\
\hline 1. & $\begin{array}{l}\text { Harus membuat rumah } \\
\text { panggung dengan bahan } \\
\text { dari bambu dengan atap } \\
\text { dari aren (injuk). }\end{array}$ & $\begin{array}{l}\text { Ramah lingkungan, karena jika } \\
\text { menggunakan bahan tembok akses ke } \\
\text { Kampung Naga agak susah karena } \\
\text { berada di lembah yang dalam, sehingga } \\
\text { dikhawatirkan akan merusak alam } \\
\text { sekitarnya ketika proses pengiriman } \\
\text { matrial bangunan. }\end{array}$ \\
\hline 2. & $\begin{array}{l}\text { Tidak boleh menebang } \\
\text { pohon besar, mengambil } \\
\text { kayu dan memetik daun } \\
\text { dari hutan }\end{array}$ & $\begin{array}{l}\text { Pohon sebagai sumber air tanah yang } \\
\text { bersih ; Hutan terjaga kelestariannya, } \\
\text { banyak terdapat pohon - pohon besar } \\
\text { yang masih kokoh. }\end{array}$ \\
\hline 3. & $\begin{array}{l}\text { Dilarang mandi di sungai } \\
\text { menggunakan sabun }\end{array}$ & $\begin{array}{l}\text { Tidak mencemari air sungai dengan zat } \\
\text { kimia yang berasal dari sabun / } \\
\text { detergen. }\end{array}$ \\
\hline
\end{tabular}




\begin{tabular}{lll}
\hline & & Hutan akan tetap terjaga dan tidak akan \\
Dilarang masuk ke $\quad \begin{array}{l}\text { terusak oleh manusia, karena dalam } \\
\text { hutan terdapat mata air yang mengalir } \\
\text { leuweung larangan / hutan } \\
\text { larangan }\end{array}$ & $\begin{array}{l}\text { ke sungai Ciwulan melewati Kampung } \\
\text { Naga. }\end{array}$
\end{tabular}

Masyarakat lokal Kampung Naga selalu menunjukan kehidupan yang sederhana, karena kesederhaan itu adalah kepercayaan yang diyakini kebenarannya oleh masyakat Kampung Naga. Kesederhanaan yang dianut masyarakat Kampung Naga juga tercermin oleh budaya yang masih tradisional ditengah kemajuan global. Dengan adanya pantangan di Kamung Naga sikap keseharian masyarakat Kampung Naga sangat menjunjung tinggi kelestarian alam termasuk hewan dan tumbuhan, mereka bertindak bukan untuk mengubah alam tetapi hidup selaras dengan alam. Pada masyarakat Kampung Naga, nilai - nilai tradisional sangat dipertahankan.

Berkat adanya kearifan lokal berupa larangan / pamali serta adanya sifat menjunjung tinggi kesederhanaan maka kearifan lokal yang ada di Kampung Naga tersebut memiliki peranan / pengaruh besar dalam menjaga serta melestarikan lingkungan alam yang ada disekitar Kampung Naga, Tasikmalaya.

\section{B. Kearifan Lokal Dalam Pelestarian Lingkungan Alam Di Sungai Jingah, Banjarmasin}

Banjarmasin terkenal dengan sebutan Kota Seribu Sungai. Hal tersebut karena posisi Banjarmasin yang dikelilingi oleh sungai - sungai besar, sehingga sungai sangat memiliki peranan penting untuk masyarakat Banharmasin. Sungai tersebut sebagai penghubung dan jalur pelayaran antar daerah. Selain itu alasan lain Banjarmasin disebut sebagai Kota Seribu Sungai yaitu karena sangat banyak sekali anak sungai dan lebih banyak lagi cabang - cabang dari anak sungai itu.Sehingga oleh sebab itu Banjarmasin disebut Kota Seribu Sungai. (Subiyakto, 2020).

Di Sungai Jingah, seiring berkembangnya teknologi, infrastuktur dan jaman, kehidupan masyarakat Sungai Jingah mengalami perubahan, baik masyarakat yang di bantaran sungai maupun bukan. Adanya kemajuan fasilitas seperti adanya jalan darat dan disediakannya air bersih, berpengaruh dalam aktivitas masyarakat dalam memanfaatkan sungai. Yang pada awalnya masyarakat menggunakan transportasi sungai, sekarang sudah banyak yang beralih ke trasnportasi darat, kemudian dengan adanya kesediaan air bersih, masyarakat menjadi tahu bahwa tidak baik jika mandi / mencuci di sungai, karena bagaimanapun juga air sungai itu kotor dan tidak baik untuk kesehatan. Sehingga masyakarat Sungai Jingah semakin sedikit yang mencuci dan mandi si sungai. Dengan adanya hal tersebut maka kualitas air sungai akan tetap 
terjaga dan tidak tercemar oleh zat kimia detergen dan zat kimia lain yang dapat mencemari sungai secara langsung.

Tetapi meskipun demikian, di Sungai Jingah sebagian besar masyarakatnya bergerak dalam bidang usaha pembuatan kain sasirangan. Tetapi hal tersebut sangat disayngan karena masyakaratnya masih membuang limbah sisa produksi kain ke sungai tanpa diolah terlebih dahulu, sehingga menyebabkan pencemaran. Dari hal itu aktivitas masyakarat masih kontras, ada yang berperan dalam mengurangi pencemaran air, dan ada yang masih mencemari sungai.

Upaya untuk mengatasi pencemaran sungai akibat limbah sisa produksi kain sasingiran yaitu masyarakat Sungai Jingah dapat mengolah terlebih dahulu limbah sisa produksi kain sasirangan dengan memberikan prioritas tertinggi pada pengelolaan limbah yang berorientasi pada pencegahan timbulan sampah, meminimalisir limbah yang dihasilkan, dan barang yang dapat dikomposisi secara biologi, serta pengaplikasian pembuangan limbah yang ramah lingkungan (Syaharuddin, 2020). Sehingga hal tersebut setidaknya akan mengurangi pencemaran lingkungan terutama pencemaran air di sungai. Adanya sikap / perilaku konsisten dan memiliki pengetahuan tentang menjaga lingkungan merupakan upaya dalam meningkatkan kesadaran lingkungan masyarakat sehingga hal tersebut sangat penting untuk melindungi lingkungan (Putra, 2021).

Kampung Sungai Jingah sealin memiliki kearifan lokal berupa kain Sasingiran, Sungai Jingah juga merupakan bagian dari wisata sungai saluran di Kota Banjarmasin. Dengan dijadikannya Sungai Jingah sebagai destinasi wisata, maka hal tersebut memberikan dampak positif / manfaat untuk masyarakat tepian Sungai Jingah terutama untuk sektor ekonomi (Putro, 2021). Sehingga masyarakat Sungai Jingah, harus memiliki kesadaran lebih dalam menjaga kearifan lokal yang ada serta diiringi dengan rasa peduli terhadap lingkungan. Selain itu, untuk memanfaatkan sungai dengan maksimal, mungkin masyarakat Sungai Jingah, dapat membuat Pasar terapung seperti yang ada di Kelurahan Alalak Selatan Banjarmasin Utara (Yuniarti, 2020). Selain itu juga bisa juga mengadakan mode transportasi sungai berupa klotok untuk menarik minat wisatawan. Klotok dapat menjadi ikon wisata sungai karena menghadirkan keunikan tersendiri bagi hadiin (Mutiani, 2020).

Nilai pada masyarakat dimaknai sebagai suatu tanggapan terhadap sikap / perilaku yang ada kaitannya dengan aktivitas masyarakat baik itu yang bersifat kelompok ataupun individu. Nilai tersebut ada yang positif (berakibat baik) dan ada pula yang neatif (berakibat buruk) pada objek yang diberi penilaian (Subiyakto, 2019). Kerusakan lingkungan termasuk kedalam sesuatu yang memiliki nilai negatif (berakibat buruk) untuk masyarakat. Pengokohan sikap lingkungan merupakan aspek 
yang harus selalu dikembangkan kepada masyarakat dan generasi selanjutnya agar kelestarian lingkungan dapat terjaga dan dipertahankan (Jumriani, 2021).

\section{PENUTUP}

\section{A. SIMPULAN}

Kearifan lokal yaitu kumpulan dari berbagai pengetahuan lokal dan pengalaman masyarakat disuatu daerah. Pada suatu kearifan lokal yang ada disuatu daerah terdapat nilai - nilai yang postitif yang terkandung didalamnya, hal tersebut karena kearifan lokal tercipta dari nilai - nilai sosial yang dihormati serta dijunjung tinggi oleh masyarakat dan memiliki fungsi sebagai suatu pedoman dalam bertingkah laku dengan sesama masyarakat / manusia, alam, maupun dengan Tuhan. Kearifan lokal harus selalu dijaga dan dilestarikan, serta masyakarat didalamnya harus menyadari dan memiliki keyakinan moral serta memiliki keyakinan spiritual bahwa manusia itu satu kesatuan dengan alam, contohnya adanya beberapa pantangan di Kampung Naga, Tasikmalaya yang mana hampir semua pantangan yang ada memiliki peranan / kaitannya dengan kelestarian alam, kemudian di daerah Sungai Jingah masyarakat masih memiliki rasa keterkaitan / rasa ketergantungan terhadap sungai sebagai tempat mandi / mencuci atau melakukan aktivitas lainnya si sekitaran sungai.

\section{B. SARAN}

- Masyarakat harus tetap menjunjung tinggi kearifan lokal di daerahnya masing masing, karena bagaimana pun juga kearifan lokal daerah terdapat nilai - nilai positif yang ada didalamnya.

- Adanya upaya pengenalan kearifan lokal ke generasi yang lebih muda, agar kearifan lokal dapat terjaga dan tidak mengalami degradasi.

- Masyarakat harus memiliki rasa cinta lingkungan yang tinggi dan selalu menjaga serta melestarikan lingkungan yang ada disekitarnya.

- Melakukan perubahan / penyesuaian terhadap kearifan lokal yang sudah tidak memiliki kebermanfaatan. 


\section{DAFTAR PUSTAKA}

Darusman, Y. (2016). Kearifan lokal dan pelestarian lingkungan (studi kasus di kampung naga, kabupaten tasikmalaya dan di kampung kuta, kabupaten ciamis). Jendela PLS, 1(1).

Dewi, I. K., \& Istiadi, Y. (2016). Mitigasi bencana pada masyarakat tradisional dalam menghadapi perubahan iklim di kampung naga kecamatan salawu kabupaten tasikmalaya (disaster mitigation on traditional community against climate change in kampong naga subdistrict salawu tasikmalaya). Jurnal Manusia dan Lingkungan, 23(1), 129-135.

Jumriani, J., Ilmiyannor, M., \& Mi'rajiatinnor, D. (2021, February). Strengthening Environmental Care Attitudes Through Social Wisdom-Based Social Studies Learning. In The 2nd International Conference on Social Sciences Education (ICSSE 2020) (pp. 65-69). Atlantis Press.

Jumriani, J., Mutiani, M., Putra, M. A. H., Syaharuddin, S., \& Abbas, E. W. (2021). The Urgency of Local Wisdom Content in Social Studies Learning: Literature Review. The Innovation of Social Studies Journal, 2(2), 103-109

Mutiani, M., Putra, M. A. H., Abbas, E. W., Subiyakto, B., \& Oktaviani, N. M. (2020). Strengthening Local River Transportation (Klotok) As River Tourist Attraction. Jhss (Journal of Humanities And Social Studies), 4(2), 152-157.

Niman, E. M. (2019). Kearifan lokal dan upaya pelestarian lingkungan alam. Jurnal Pendidikan dan Kebudayaan MISSIO, 11(1), 91-106.

Nurkamilah, C. (2018). Etika lingkungan dan implementasinya dalam pemeliharaan lingkungan alam pada masyarakat Kampung Naga. Jurnal Studi Agama-agama dan Lintas Budaya, 2(2), 136-148.

Putra, M. A. H., \& Subiyakto, B. (2021, February). Ecological Awareness Based on Religious Activities. In The 2nd International Conference on Social Sciences Education (ICSSE 2020) (pp. 311-314). Atlantis Press.

Putro, H. P. N., Jumriani, J., Abbas, E. W., \& Aprilla, W. (2021, February). Impact of Tourism for Economic Activities of Riverbank Communities in the Jingah River District, Banjarmasin City. In The 2nd International Conference on Social Sciences Education (ICSSE 2020) (pp. 371-374). Atlantis Press.

Putro, H.P.N., Jumriani, J., Darmawan, D., \& Nuryatin, S. (2020). Social Life of the Community: Perspective of Riverbanks Community in Sungai Jingah, Banjarmasin. The Kalimantan Social Studies Journal, 1(2), 151-158 
Qodariah, L., \& Armiyati, L. (2013). Nilai-Nilai kearifan lokal masyarakat adat Kampung Naga sebagai alternatif sumber belajar. SOCIA: Jurnal Ilmu-Ilmu Sosial, 10(1).

Sartini, S. (2004). Menggali kearifan lokal Nusantara: Sebuah kajian filsafati. Journal filsafat, 14(2), 111-12-.

Subiyakto, B., \& Mutiani, M. (2019). Internalisasi nilai pendidikan melalui aktivitas masyarakat sebagai sumber belajar ilmu pengetahuan sosial. Khazanah: Jurnal Studi Islam dan Humaniora, 17(1), 137-166.

Subiyakto, B., Abbas, E. W., Arisanty, D., Mutiani, M., \& Akmal, H. (2020). Sungai dan Kehidupan Masyarakat Banjar: Penguatan Lokalitas dalam Wacana Pendidikan IPS yang Responsif.

Syaharuddin, S., Samihati, M., \& Jumriani, J. (2020). Aktualisasi Sikap Peduli Lingkungan Melalui Aktivitas Pengelolaan Sampah. Jurnal Socius, 9(2), 193-203.

Thamrin, H. (2013). Kearifan Lokal dalam Pelestarian Lingkungan (The Local Wisdom in Environmental Sustainable). Kutubkhanah. 6 (1), 46-59.

Yuniarti, D., Subiyakto, B., \& Putra, M. A. H. (2020). Economic Activities in Kuin Floating Market as a Learning Resource on Social Studies. The Kalimantan Social Studies Journal, 1(2), 130-140. 